\title{
A Strategy for Quantifying Radioactive Material in a Low-Level Waste Incineration Facility
}

by

R. C. Hochel

Westinghouse Savannah River Company

Savannah River Site

Aiken, South Carolina 29808

MASTER

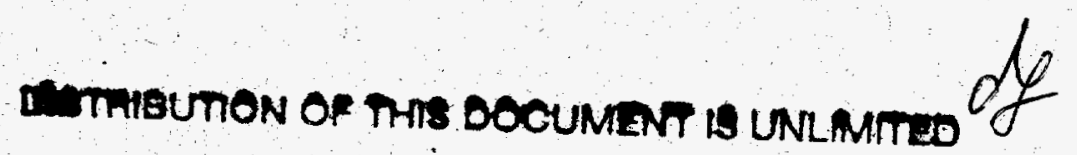

DOE Contract No. DE-AC09-96SR18500

This paper was prepared in connection with work done under the above contract number with the $U$. S. Department of Energy. By acceptance of this paper, the publisher and/or recipient acknowledges the U.S. Government's right to retain a nonexclusive, royalty-free license in and to any copyright covering this paper, along with the right to reproduce and to authorize others to reproduce all or part of the copyrighted paper. 


\section{DISCLAIMER}

This report was prepared as an account of work sponsored by an agency of the United States Government. Neither the United States Government nor any agency thereof, nor any of their employees, makes any warranty, express or implied, or assumes any legal liability or responsibility for the accuracy, completeness, or usefulness of any information, apparatus, product, or process disclosed, or represents that its use would not infringe privately owned rights. Reference herein to any specific commercial product, process, or service by trade name, trademark, manufacturer, or otherwise does not necessarily constitute or imply its endorsement, recommendation, or favoring by the United States Government or any agency thereof. The views and opinions of authors expressed herein do not necessarily state or reflect those of the United States Government or any agency thereof.

This report has been reproduced directly from the best available copy.

Available to DOE and DOE contractors from the Office of Scientific and Technical Information, P.O. Box 62, Oak Ridge, TN 37831; prices available from (615) 576-8401.

Available to the public from the National Technical Information Service, U.S. Department of Commerce, 5285 Port Royal Road, Springfield, VA 22161. 


\section{DISCLAIMER}

Portions of this document may be illegible electronic image products. Images are produced from the best available original document. 
WESTINGHOUSE SAVANNAH RIVER COMPANY SAVANNAH RIVER TECHNOLOGY CENTER

ANALYTICAL DEVELOPMENT SECTION
WSRC-TR-97-0106 Revision 0

KEY WORDS:

Beta-Gamma

Alpha

Low-Level Waste

Transuranic Waste

Solid Waste Disposal

RETENTION:

Permanent

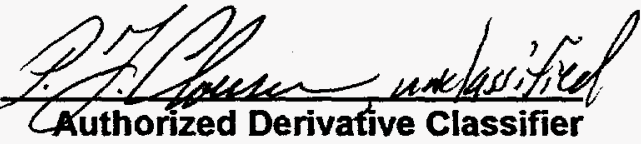

\section{A STRATEGY FOR QUANTIFYING RADIOACTIVE MATERIAL IN A LOW-LEVEL WASTE INCINERATION FACILITY (U)}

By

R. C. Hochel

March,1997 


\section{Introduction}

One of the methods proposed by the U.S. Department of Energy (DOE) for the volume reduction and stabilization of a variety of low-level radioactive wastes (LLW) is incineration. Many commercial incinerators are in operation treating both non-hazardous and hazardous wastes. These can obtain volume reductions factors of 50 or more for certain wastes, and produce a waste (ash) that can be easily stabilized if necessary by vitrification or cementation. However, there are few incinerators designed to accommodate radioactive wastes. One has been recently built at the Savannah River Site (SRS) near Aiken, SC and will be burning non-radioactive hazardous waste and radioactive wastes in successive campaigns.

The SRS Consolidated Incineration Facility (CIF) is RCRA (Resource Conservation and Recovery Act) permitted as a Low Chemical Hazard, Radiological facility as defined by DOE criteria. ${ }^{1}$ Accordingly, the CIF must operate within specified chemical, radionuclide, and fissile material inventory limits. ${ }^{2}$ The radionuclide and fissile material limits are unique to radiological or nuclear facilities, and require special measurement and removal strategies to assure compliance. If certain limits are reached, the CIF may be required to shut down periodically in order to clean out the radionuclide inventory which could buildup in various parts of the facility.

This paper describes a strategy for quantifying the amounts of various radionuclides likely to reside in the facility under normal operations. Combining a small number of sample analyses with site-specific process knowledge allows many operational issues to be addressed. These include radiological and nuclear safety, radionuclide inventories in various CIF components, and compliance with regulatory requirements for operations and waste disposal.

\section{CIF Component and Waste Tracking System Description}

Major facility components, inputs, and outputs are shown in the process flow schematic in Figure 1. The CIF uses a rotary kiln, secondary combustion, wet/dry offgas, and inline ash solidification technologies. It is one of three mixed waste incinerators within the DOE complex: Oak Ridge has a rotary kiln incinerator and Idaho has a fixed hearth incinerator. The CIF is unique with four burning options: aqueous liquids ( $430 \mathrm{~kg} / \mathrm{hr}$ ), blended liquids $(175 \mathrm{~kg} / \mathrm{hr}$ ), solids $(435 \mathrm{~kg} / \mathrm{hr})$, and benzene $(86 \mathrm{~kg} / \mathrm{hr})$. 
Figure 1 CIF Process Flow Schematic

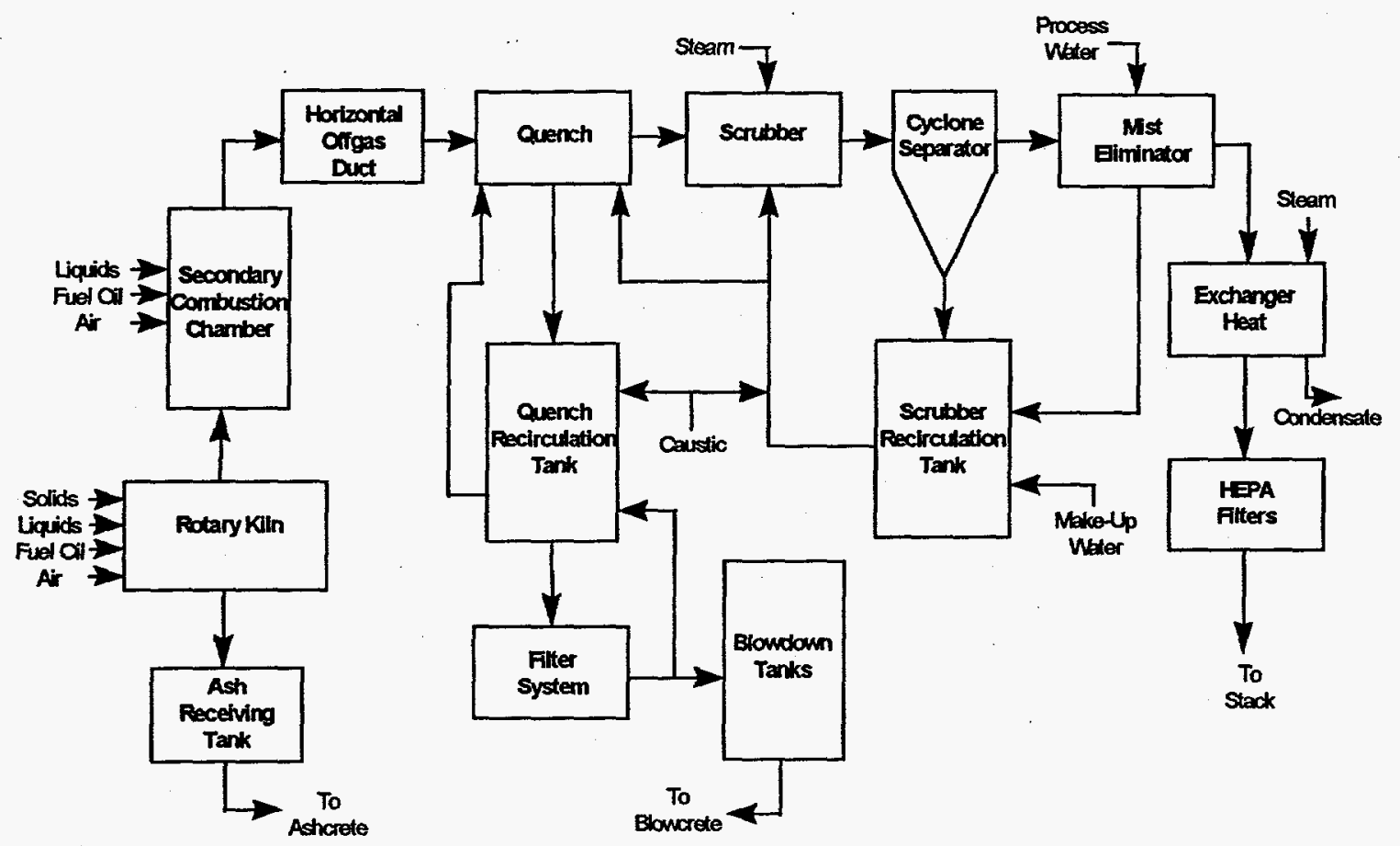

Based on design and operational characteristics of pilot and similar facilities, the weights of ash expected to be held up in each of the major components of the CIF have been modeled. The CIF inventory model assumes that all the retained ash will approach an average concentration determined from the volume and radionuclide characteristics of the input feeds processed between cleanouts. With the exception of tritium and several other volatile components in wastes, all radionuclides and heavy metals are assumed to concentrate almost exclusively in the ash. Tritium is expected to partition equally in the water circulating tanks in the offgas handling components. Tritium is also continually lost to the stack because of water vapor carried in the offgas air flow, which is maintained even when waste is not being burned. This loss is estimated from the amount of makeup-water that must be added to maintain a mass balance. A stack air activity monitor is available for measuring tritium in the stack effluent from collected sample periodically analyzed by liquid scintillation.

The CIF uses a Waste Tracking System (WTS) to keep a running inventory of radionuclides within two facility segments. Inventory limits for each segment are the same but apply independently. The WTS assumes a curie balance based on waste feed inputs and ash/stack outputs. However, some curie inputs are too low to measure and must be estimated from waste stream characterization data, which is typically biased high. Radionuclide concentrations estimated by the 
WTS, therefore, are expected to be conservatively high also. Whenever the holdup inventories in individual components or facility segments reach certain values, as estimated by the WTS, an analytical assessment of actual inventories, and possibly a cleanout, will be necessary.

The CIF will burn both solids and appropriate liquid wastes from across the site. These include solid job-control waste and liquid streams of benzene, spent solvents, tritiated oils, and other miscellaneous organic/aqueous blends. Each of these has differing radionuclide distributions, so in practice, input streams can be varied to maximize cleanout intervals.

Ideally, from operational experience, appropriate sampling and analyses, and verification of the WTS performance, it may be possible to avoid the need for CIF cleanouts almost entirely. But this is too consequential to leave untested, so a strategy to verify the activity balance and inventory from a combination of process knowledge information, and input, output, and holdup measurements was developed.

\section{Radionuclide Inventory Limits}

The CIF must track a sizable list of radionuclides which comes from Reference 3 and is included in the appendix. Each radionuclide has an individual limit and the total sum of the individual fractions must be maintained below one. The limits are the threshold values which would cause the facility to be classified in the next higher, Hazard Category 3 (HC3), level. The reciprocal of each value is called an Inventory Control Factor (ICF). The product of the ICF and the number of curies of that radionuclide must be less than one for the facility. The larger the ICF, the more restrictive is that radionuclide. A quick scan of the appendix list shows that $\mathrm{Sr}-90$ and the transuranics like Pu-239 are generally the most limiting.

The SRS waste streams destined for incineration are contaminated primarily with aged fission and activation products. So, many of the radionuclides in the list, having comparatively short half-lives, will be absent and of no concern. To simplify the burden of analyzing for all the possible radionuclides, only those contributing to $90 \%$ of the $\mathrm{HC} 3$ limit, as tracked by the WTS, are specifically measured for. Additionally, any activities greater than $10 \%$ of the total in samples will be identified, while those less than $10 \%$ will be classed appropriately as "Other Alpha" or "Other Beta/Gamma" to assure conservative tracking of the $\mathrm{HC} 3$ facility limit.

\section{Radionuclide Inventory Assessment}

To effectively assess the inventory of radionuclides within the CIF first requires a sound quantification strategy. This must be based on the ability to sample input 
and output streams, and to sample, monitor, or clean most of the individual components within the facility. Process knowledge from operation of other incinerators and cold operation of the CIF has determined where ash buildup occurs. Aside from losses of gases or vapors such as tritium in HTO or C-14 in $\mathrm{CO}_{2}$, all radionuclides incinerated will remain mostly in the ash. Smaller amounts of soluble species will dissolve in the quench and scrubber waters. Some of the insoluble sludges and ash will also plate or deposit on certain internal surfaces. The amount of plate-out is expected to be roughly proportional to surface areas of the exposed storage tanks or processing components.

It is estimated that $75 \%$ of the ash from solids will fall into the Receiving Tank from the Rotary Kiln and Secondary Combustion Chamber. The remaining $25 \%$ of the solids ash along with $100 \%$ of the ash from liquids will be mostly carried out of the Secondary Combustion Chamber as particulates, and into the offgas components and process waters. Site experts familiar with the accumulation of material (holdup), and how to best remove it and quantify the results, looked in detail at the design and construction of the CIF. The major components containing significant inventories as solids or liquids are listed in Table 1. The table also lists the volumes, surface areas, and solid or equivalent ash weights expected in the components for maximal operating inventories.

Table 1. CIF Component Sizes and Expected Total Ash Inventories

\begin{tabular}{|c|c|c|}
\hline 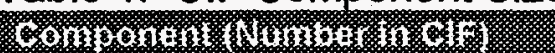 & 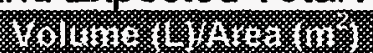 & 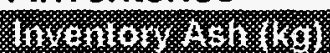 \\
\hline Aqueous Waste Tank & $24,500 / 48.8$ & 245 \\
\hline Blend Tank (2) & $16,000 / 37.2$ & 160 \\
\hline Spare Feed Tank & $24,500 / 48.8$ & 245 \\
\hline Solid Waste Boxes $(500)$ & $150 / \mathrm{NR}$ & 570 \\
\hline Ash Receiving Tank & NR/48.8 & 635 \\
\hline Rotary Kiln & $\mathrm{NR/83.6}$ & 75 \\
\hline Secondary Combustion Chamber & $N R / 51.1$ & 175 \\
\hline Horizontal Offgas Duct & NR/67.4 & 265 \\
\hline Quench Recirculation Tank & $22,700 / 46.5$ & 1250 \\
\hline Scrubber Recirculation Tank & $15,100 / 34.8$ & 760 \\
\hline Filter Feed Tank & $15,100 / 34.8$ & 1330 \\
\hline Blowdown Hold Tank (2) & $22,700 / 46.5$ & 5290 \\
\hline Ashcrete Drum (5) & $200 / \mathrm{NR}$ & 415 \\
\hline Blowcrete Drum (5) & 200/NR & 200 \\
\hline HEPA Filter/Housing (3) & $N R / 41.8$ & 50 \\
\hline
\end{tabular}

The surface areas are useful in identifying the relative importance of holdup in similar components, although surface type and geometry are more important in determining the magnitude of potential holdup. Values not relevant to calculating inventories are indicated "NR" in the table.

The CIF operates primarily in a batch mode. Both solid and liquid input inventories can be varied by adjusting both the type and volume of waste (batches) to be processed. Liquid Feed will consist of organics or 
aqueous/organic blends. There are four tanks for preprocessing and storing liquid feed to the CIF. A maximum operating inventory assumes all but one of the tanks (a Blend Tank) are full. The equivalent ash content of liquids is assumed to be $1 \%$ by weight. Because of their low ash content, liquids typically do not contribute much to radionuclide inventory unless they are highly radioactive or contain mostly Sr-90 or transuranics, which have very low HC3 values. These tanks constitute their own facility segment, and do not affect allowable inventories in the rest of the facility. They can be easily sampled for accurate radionuclide quantification.

All Solid Waste is in cardboard boxes and enters the Rotary Kiln unopened. The inventory of radionuclides from solid feed must be computed from manifests provided by the site's waste generators. Manifests for most boxed-solids are based on process knowledge with little direct verification, because radionuclide levels in any one box are usually too low to accurately measure. ${ }^{4}$ However, with the input of many boxes, the average radionuclide inventory computed from individual manifests should be relatively accurate. It is assumed the solid waste handling area will be maintained free of radioactive contamination and will have zero holdup. Upon incineration, solid waste is assumed to generate $5 \%$ ash by weight. This mass of ash is further assumed to partition $75 \%$ to the Ash Receiving Tank and $25 \%$ to the Secondary Combustion Chamber and the offgas handling components. All of the solid waste activity concentrates in the fraction of ash going to the Receiving Tank. By contrast, all activity and ash from liquid feeds is assumed to be carried exclusively to components downstream of the Secondary Combustion Chamber.

The Ash Receiving Tank is a water tank that catches ash as it falls from the exit end of the Rotary Kiln. It is assumed to contain nearly all the ash and nonvolatile radionuclides produced from the burning of Solid Waste. Wet ash will be sampled and mixed with cement in 55-gallon (200 liter) drums to form "Ashcrete" for final disposal. The ashcrete drums nominally contain about 83 kilograms of ash each. A radiochemical analysis of the ash will be used to verify solid feed inputs and manifest ashcrete drums.

The Rotary Kiln, Secondary Combustion Chamber, and a Horizontal Offgas Duct, which connects the vertical Secondary Combustion Chamber and Quench vessel, all will contain plated or deposited ash that will require occasional cleanout. The frequency of such cleanouts will be determined from visual inspections, which are possible for all three components. When performed, the recovered ash can be radiochemically analyzed and disposed of as Ashcrete.

The Offgas Quench and Scrubber Tanks will contain water, dissolved salts, and fine particulates formed in the Secondary Combustion Chamber. These tanks are allowed to accumulate ash and salt before being emptied to Blowdown (Hold) Tanks. Again this material will be mixed with cement to form "Blowcrete". 
These tanks will be sampled for liquid and solids, and radiochemically analyzed. Results will be used to manifest all Blowcrete drums from a given hold-tank batch. The ash inventory in these tanks is based on the total expected suspended and sludge solids in each.

Blowcrete drums are expected to contain about 40 kilograms of ash each.

The HEPA Filters will contain any solids which manage to escape from the offgas treatment section of the facility. Carryover of some of the water soluble radionuclides is also likely. The filters will be sampled and analyzed when it is necessary to change them. The maximum ash loading on a HEPA filter is assumed to be about 16 kilograms.

All of the other CIF components are exposed to water spray or water-saturated air in operation, and are assumed to have no significant holdup. This, however, will be checked by visual or instrumental inspection.

\section{Use of the Radiochemical Analysis Data}

Based on the radiochemical analysis data obtained as described above, it will be possible to establish a curie balance of radionuclides input and output within the CIF. This will, in turn, allow verification or modification of the WTS. Use of the WTS is seen as essential for efficient and cost effective utilization of the CIF. Without it, the CIF may be forced into cleanout shutdowns for the lack of documented data to show they might be unnecessary otherwise. Unnecessary cleanouts will generate additional waste and possibly new waste streams, and are to be avoided if possible.

All of the site's waste generators are required to characterize the wastes they produce. ${ }^{5}$ Specifics of the characterization depend on the intended storage, treatment, or disposal facility and must meet certain Waste Acceptance Criteria (WAC). The CIF is a treatment facility and a waste generator. The WAC for liquids and solids to be burned in the CIF are specified in Reference 6. Radionuclide limits are shown in Table 2.

Table 2. Maximum CIF Feed Concentrations

\begin{tabular}{|c|c|c|}
\hline 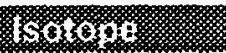 & 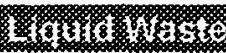 & Sordust/m \\
\hline & $(\mathrm{nCi} / \mathrm{g})$ & $(\mathrm{nC \textrm {C } / \mathrm { g } )}$ \\
\hline Alpha & 51 & 58 \\
\hline Tritium & 3417 & 604 \\
\hline Beta-Gamma & 5769 & 22,955 \\
\hline
\end{tabular}

The beta-gamma limits exclude tritium, which is specified separately. As mentioned above, solid waste feed must be based primarily on the manifests supplied by the site waste generators. However, liquid feeds should be verified from sample analysis. 
Waste from the CIF in the form Ashcrete and Blowcrete Drums will likely have to meet criteria similar to those for the site's LLW disposal vaults. The maximum radionuclides concentrations are listed in Table 3, and were derived from Reference 7.

Table 3. Maximum LLW Vault Radionuclides Concentrations

\begin{tabular}{|l|c|l|c|}
\hline Isotope & WAC Limit & Isotope & WAC Limit \\
\hline & (nCi/g) & & (nCi/g) \\
\hline $\mathrm{H}-3$ & $1.0 \mathrm{E}+04$ & $\mathrm{Pr}-144 \mathrm{~m}$ & $1.7 \mathrm{E}+02$ \\
\hline $\mathrm{C}-14$ & $3.3 \mathrm{E}+00$ & $\mathrm{Pm}-147$ & $1.4 \mathrm{E}+04$ \\
\hline $\mathrm{Ni}-59$ & $6.3 \mathrm{E}+01$ & $\mathrm{U}-233$ & $3.3 \mathrm{E}-02$ \\
\hline $\mathrm{Co}-60$ & $2.3 \mathrm{E}+04$ & $\mathrm{U}-234$ & $7.5 \mathrm{E}+00$ \\
\hline Se-79 & $5.2 \mathrm{E}-01$ & $\mathrm{U}-235$ & $1.1 \mathrm{E}-01$ \\
\hline $\mathrm{Sr}-90$ & $1.1 \mathrm{E}+03$ & $\mathrm{U}-236$ & $1.4 \mathrm{E}+00$ \\
\hline $\mathrm{Y}-90$ & $1.1 \mathrm{E}+03$ & $\mathrm{U}-238$ & $2.3 \mathrm{E}+00$ \\
\hline TC-99 & $1.7 \mathrm{E}-01$ & $\mathrm{~Np}-237$ & $2.2 \mathrm{E}-02$ \\
\hline Ru-106 & $1.4 \mathrm{E}+04$ & Pu-238 & $9.1 \mathrm{E}+01$ \\
\hline Rh-106 & $1.4 \mathrm{E}+04$ & Pu-239,240 & $9.1 \mathrm{E}+01$ \\
\hline Sn-126 & $2.9 \mathrm{E}-01$ & Pu-241 & $1.1 \mathrm{E}+03$ \\
\hline $\mathrm{I}-129$ & $8.3 \mathrm{E}-05$ & Pu-242 & $9.1 \mathrm{E}+01$ \\
\hline $\mathrm{Cs}-137$ & $7.6 \mathrm{E}+02$ & Am-241 & $9.1 \mathrm{E}+01$ \\
\hline Ba-137m & $7.3 \mathrm{E}+02$ & Other Beta-Gamma & $2.3 \mathrm{E}+03$ \\
\hline Ce-144 & $1.4 \mathrm{E}+04$ & Other Alpha & $3.7 \mathrm{E}+00$ \\
\hline Pr-144 & $1.4 \mathrm{E}+04$ & & \\
\hline
\end{tabular}

The LLW WAC requires characterization for all the radionuclides in Table 3 as a minimum. The concentrations are based on an assumed bulk waste density of $0.4 \mathrm{~g} / \mathrm{cc}$. Although this is much lower than the densities of Ashcrete and Blowcrete Drums (about $1.8 \mathrm{~g} / \mathrm{cc}$ ), the table values cannot be increased accordingly if drums are to remain below $100 \mathrm{nCi} / \mathrm{g}$ in transuranics. Because the CIF feeds are the combustible portions of typical site LLW, levels in Table 2 and Table 3 are necessarily similar. But with the large concentration of most radionuclides in the ash upon burning, feeds, on average, will need to be much more dilute than those in Table 2.

To assure WAC compliance, the actual distribution of the radionuclides in drums need to be established initially and verified periodically. For those radionuclides which cannot be readily measured analytically, process knowledge may be used to infer a distribution, such as from fission product ratios to Cs-137 or activation ratios to Co-60. This will not be easy for the CIF. The high temperatures encountered in the incineration process and solubility of certain nuclides in the process waters may alter any distribution so inferred. Therefore, radiochemical analyses should be obtained where possible. Once the distribution is established, a dose-to-curie methodology may be used to help manifest outgoing waste packages (55-gallon drums). 


\section{Operational Inventory Control}

Determining how normal facility processing inventories will compare against the HC3 limits requires characterization and quantities of various stored feed streams, the amounts and locations of ash produced from their incineration, and estimates or measurements of output waste losses. At any given time, the radionuclide inventory will depend on the waste stream being actively burned and, to varying extents, that previously burned. A worst case is assumed by combining radionuclides from the annual burning of all feeds and evenly distributing the total activity in the total mass of the resulting ash. The radionuclide inventory in the facility at any time, then, can be approximated from the amount of ash it contains.

The maximum annual radioactive feed input to the CIF is estimated at 682 tonnes of solids, 167 tonnes of benzene, 127 tonnes of miscellaneous mixed liquids, and 15 tonnes of tritiated liquids. The ash content of the solids is about $5 \%$ while the liquids is about $1 \%$. These wastes have been crudely characterized as to a few of their major activities, H-3, Co-60, Cs-137, and sometimes other beta-gamma emitters or Pu-238 or Pu-239, but a more complete list of radionuclides likely in SRS wastes is that in Table 3. Because the strong gamma-emitter Cs-137, a fission product, was almost always characterized reasonably well, the other fission products of Table 3 were inferred from fission yield data. ${ }^{8}$ Similarly, actinide activities relative to Cs-137 are well known from their nuclear genesis at the site and can be estimated from computer codes such as Reference 9. Other nuclides, such as tritium and activation products, were estimated from process knowledge or characterization data if it was judged reliable. The resultant homogenized distribution of these wastes is shown in the second column of Table 4.

Table 4. Worst Case CIF Radionuclide Inventories and HC3 Limit

\begin{tabular}{|c|c|c|c|c|c|c|}
\hline 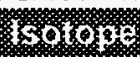 & 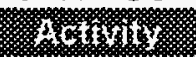 & Srit for & 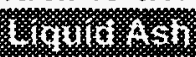 & ses & S6y & Sten \\
\hline & Distribution & $(\mathrm{Ci} / \mathrm{kg})$ & $(\mathrm{Ci} / \mathrm{kg})$ & $(1 / \mathrm{Ci})$ & Fraction & Fraction \\
\hline $\mathrm{H}-3$ & $3.91 E-03$ & $(1.18 E+02)$ & $(8.33 E+02)$ & $1.00 E-03$ & $(8.33 E-01)$ & $(1.18 E-01)$ \\
\hline$C-14$ & 1.65E-05 & 1.93E-09 & $6.66 \mathrm{E}-09$ & $2.38 \mathrm{E}-03$ & 3.39E-08 & 1.55E-07 \\
\hline $\mathrm{Ni}-59$ & $1.94 \mathrm{E}-05$ & $2.28 \mathrm{E}-09$ & $7.85 \mathrm{E}-09$ & $8.47 \mathrm{E}-05$ & $1.42 \mathrm{E}-09$ & $6.52 E-09$ \\
\hline Co-60 & $6.56 \mathrm{E}-03$ & $1.92 \mathrm{E}-05$ & $2.66 \mathrm{E}-06$ & $3.57 \mathrm{E}-03$ & 2.03E-05 & $2.04 \mathrm{E}-04$ \\
\hline Se-79 & 4.41E-06 & $5.17 E-10$ & $1.78 E-09$ & $2.78 \mathrm{E}-03$ & $1.06 \mathrm{E}-08$ & $4.86 \mathrm{E}-08$ \\
\hline Sr-90 & $5.36 \mathrm{E}-01$ & $6.28 \mathrm{E}-05$ & 2.17E-04 & $6.25 \mathrm{E}-02$ & 2.89E-02 & 1.33E-01 \\
\hline$Y-90$ & $5.36 \mathrm{E}-01$ & $6.28 \mathrm{E}-05$ & $2.17 E-04$ & $7.09 E-04$ & $3.28 E-04$ & $1.51 E-03$ \\
\hline TC-99 & $1.65 \mathrm{E}-04$ & $1.93 E-08$ & $6.66 \mathrm{E}-08$ & $5.88 E-04$ & $8.37 E-08$ & $3.84 \mathrm{E}-07$ \\
\hline Ru-106 & $3.43 E-02$ & 4.03E-06 & 1.39E-05 & 1.00E-02 & 2.97E-04 & $1.36 \mathrm{E}-03$ \\
\hline Rh-106 & $3.43 E-02$ & 4.03E-06 & 1.39E-05 & $5.10 \mathrm{E}-04$ & 1.51E-05 & $6.95 E-05$ \\
\hline$S n-126$ & $5.29 \mathrm{E}-07$ & $6.20 \mathrm{E}-11$ & $2.14 \mathrm{E}-10$ & $5.88 \mathrm{E}-03$ & $2.69 E-09$ & $1.23 E-08$ \\
\hline $1-129$ & $3.00 \mathrm{E}-07$ & $3.52 \mathrm{E}-11$ & $1.21 \mathrm{E}-10$ & $1.67 \mathrm{E}-01$ & $4.33 E-08$ & $1.99 \mathrm{E}-07$ \\
\hline Cs-137 & $1.00 E+00$ & 1.17E-04 & $4.05 E-04$ & 1.67E-02 & $1.44 E-02$ & 6.63E-02 \\
\hline
\end{tabular}


Table 4 Continued

\begin{tabular}{|c|c|c|c|c|c|c|}
\hline xoloyr & 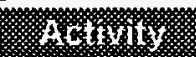 & 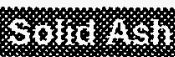 & (3) & (y) & 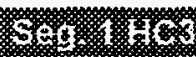 & 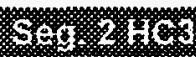 \\
\hline & Distribution & (Ci/kg) & (Ci/kg) & (1/Ci) & Fraction & Fraction \\
\hline $\mathrm{Ba}-137 \mathrm{~m}$ & $9.46 \mathrm{E}-01$ & $1.11 E-04$ & 3.83E-04 & $0.00 E+00$ & $0.00 E+00$ & $0.00 E+00$ \\
\hline $\mathrm{Ce}-144$ & $4.09 E-02$ & $4.80 E-06$ & $1.66 \mathrm{E}-05$ & $1.00 \mathrm{E}-02$ & $3.54 \mathrm{E}-04$ & $1.62 \mathrm{E}-03$ \\
\hline Pr-144 & $4.04 \mathrm{E}-02$ & $4.74 E-06$ & $1.64 E-05$ & $9.62 E-07$ & $3.36 \mathrm{E}-08$ & $1.54 \mathrm{E}-07$ \\
\hline $\mathrm{Pr}-144 \mathrm{~m}$ & 4.91E-04 & $5.76 E-08$ & $1.99 \mathrm{E}-07$ & $0.00 \mathrm{E}+00$ & $0.00 \mathrm{E}+00$ & $0.00 \mathrm{E}+00$ \\
\hline Pm-147 & 4.70E-01 & 5.52E-05 & 1.90 E-04 & $1.00 \mathrm{E}-03$ & 4.07E-04 & 1.87E-03 \\
\hline U-233 & $2.87 E-12$ & $3.36 E-16$ & $1.16 \mathrm{E}-15$ & $2.38 E-01$ & $5.90 E-13$ & $2.71 E-12$ \\
\hline U-234 & $4.59 \mathrm{E}-05$ & $5.39 \mathrm{E}-09$ & $1.86 E-08$ & $2.38 \mathrm{E}-01$ & $9.45 E-06$ & $4.34 E-05$ \\
\hline U-235 & 2.00E-06 & $2.34 E-10$ & $8.09 E-10$ & $6.45 \mathrm{E}+02$ & $1.11 E-03$ & $5.12 E-03$ \\
\hline U-236 & $7.29 E-06$ & $8.55 E-10$ & $2.95 E-09$ & $2.38 \mathrm{E}-01$ & 1.50 E-06 & $6.88 \mathrm{E}-06$ \\
\hline U-238 & $1.29 E-04$ & $1.52 E-08$ & $5.23 E-08$ & $2.38 E-01$ & $2.66 \mathrm{E}-05$ & $1.22 \mathrm{E}-04$ \\
\hline Np-237 & $3.07 \mathrm{E}-06$ & $3.60 \mathrm{E}-10$ & $1.24 \mathrm{E}-09$ & $2.38 E+00$ & $6.31 \mathrm{E}-06$ & $2.90 \mathrm{E}-05$ \\
\hline $\mathrm{Pu}-238$ & 1.07E-02 & 1.25E-06 & 4.32E-06 & $1.61 \mathrm{E}+00$ & $1.48 \mathrm{E}-02$ & $6.82 E-02$ \\
\hline Pu-239 & 2.65E-02 & 3.11E-06 & 1.07E-05 & $1.92 E+00$ & 4.41E-02 & $2.02 E-01$ \\
\hline Pu-240 & $5.95 E-03$ & $6.98 \mathrm{E}-07$ & $2.41 \mathrm{E}-06$ & $1.92 E+00$ & $9.87 \mathrm{E}-03$ & $4.53 \mathrm{E}-02$ \\
\hline $\mathrm{Pu}-241$ & 2.19E-01 & $2.57 \mathrm{E}-05$ & $8.85 \mathrm{E}-05$ & $3.13 \mathrm{E}-02$ & $5.92 \mathrm{E}-03$ & $2.72 E-02$ \\
\hline $\mathrm{Pu}-242$ & $1.94 \mathrm{E}-07$ & $2.28 E-11$ & $7.85 \mathrm{E}-11$ & $1.61 \mathrm{E}+00$ & $2.70 E-07$ & $1.24 \mathrm{E}-06$ \\
\hline Am-241 & 8.17E-04 & $9.58 E-08$ & 3.31E-07 & $1.92 E+00$ & $1.36 E-03$ & 6.22E-03 \\
\hline HC3 Sum & & & & & $9.55 \mathrm{E}-01$ & $5.60 \mathrm{E}-01$ \\
\hline
\end{tabular}

For this distribution, wastes are assumed to be about eight years old, and the fission product content is computed from the average yields for the predominant fuels and targets used at SRS. A few isotopes were further adjusted to match values with existing analyses.

Columns three and four show the activities per kilogram of solid and liquid generated ash, respectively. The ash from solids contains the incinerated radionuclides from all the solid feeds distributed in $75 \%$ of the resulting 34,100 kilograms of ash. The 118 curies of tritium in the waste are assumed lost to the stack. The ash from liquids contains all the incinerated radionuclides from liquid feeds distributed in the resulting 3090 kilograms of ash from the liquids plus the remaining $25 \%$ ( 8525 kilograms) of the clean solids ash. Here, 833 curies of tritium are assumed lost to the stack.

Column five lists the Inventory Control Factors from the appendix for radionuclides likely in SRS wastes.

The last two columns of the table list the $\mathrm{HC} 3$ fractions represented by each nuclide in Segment 1 feed tanks and the Segment 2 incinerator components, respectively. These values are obtained by multiplying the curies of each radionuclide in the Segment by the ICFs. For Segment 1, the curies are obtained by assuming that all of the tanks, except one Blend Tank, are full of liquid representative of the annual average of all the liquid feed streams. The sum of the HC3 fractions for Segment 1 is 0.955 , but most of this $(0.833)$ is due to the yearly tritium inventory assumed to be in the tanks. It is unlikely that this amount 
of tritium would actually be in the tanks at any one time, so the segment will be well below the $\mathrm{HC} 3$ unity limit in most cases.

The inventory of ash in Segment 2 components is not as straight forward as the previous case. Ash from solid and liquid feeds partition differently. For solids, $100 \%$ of the activity, except for $\mathrm{H}-3$, is assumed to concentrate totally within the $75 \%$ of the ash weight which accumulates in the Ash Receiving Tank. The remaining $25 \%$ of the ash weight, absent any activity, passes into the Secondary Combustion Chamber and beyond. The total activity and ash from liquids, on the other hand, gets mixed and diluted with the nonradioactive fraction of solids ash in the Secondary Combustion Chamber. The bulk of this mixed ash then partitions downstream. Part of the Segment 2 inventory then consists of the equivalent solids ash weight of $570 \mathrm{~kg}$ from feed boxes, $635 \mathrm{~kg}$ in the Ash Receiving Tank, $415 \mathrm{~kg}$ in five Ashcrete Drums, and $75 \mathrm{~kg}$ as deposits in the Rotary Kiln. For the remaining components, the remainder of the segment inventory from the liquids ash is partitioned as shown in Table 1. Here the HC3 fraction sum is 0.555 , which is well below the segment unity limit. However, it excludes the H-3 fraction, most of which will be lost to the stack offgas.

\section{Cleanout Methodology}

Site experts also looked at various ways to effectively clean out components found to contain residual radioactivity after normal inventory reduction practices such as emptying and flushing tanks and removing visible accumulations of solids. Invariably, removing residual material will generate additional waste and possibly new waste streams. Such removals will seldom be $100 \%$ effective, so some amount of radioactivity will remain no matter how much cleaning is done. Attempts at cleanout need to be done with these facts fully in mind.

One of the best ways to minimize unneeded cleanouts is to conduct good contamination and radiation dose surveys at fixed points on the components likely to accumulate material. Nearly all radioactive wastes incinerated will contain some Co-60 and/or Cs-137. Both of these nuclides produce energetic gamma rays, which can be detected even through several inches of steel or six to 12 inches of lighter shielding materials. By monitoring such locations before radioactive startup, and later after normal operational ash and blowdown removals, any appreciable buildup of radioactive material can be detected and monitored. Visual inspections, where possible, may also be good for detecting buildups. These may be by eye or by camera with the aid of a borescope if necessary. Most CIF tanks and components can be visually inspected.

Assuming a component shows visual or dose indications of significant material buildup, the next step is to obtain a sample of the material for analysis. This may already be partially available for those components containing batch material sampled and analyzed as recommended above; however, simple confirmatory 
checks should be made to assure the materials are the same. The object is to determine the types of activities present in the major contaminants. Alphaemitters are of primary concern because of radiological and nuclear safety issues. If these nuclides are sufficiently low in the holdup material, a cleanout may not be necessary. Liquid scintillation spectroscopy of filter paper smear samples is an excellent way to obtain this information quickly, as alpha and beta activities are usually easily distinguishable from one another even with little sample preparation or chemistry. ${ }^{10}$

If a cleanout is necessary, it should generate relatively innocuous wastes in minimal quantities. Decontamination experience at SRS is that progressive treatments with $1-5 \mathrm{wt} \%$ nitric acid solutions between 75 and $90^{\circ} \mathrm{F}$ generally work well. This may be done by simple filling and agitation. The cleaning solution can be analyzed periodically (every 4 hour) to monitor progress of the cleaning. After draining the cleaning solution, a simple water flush with a hose finishes the process.

\section{Quantifying Unremovable Residual Contamination in Components}

As mentioned above, cleaning is seldom totally effective. Some contamination is likely to remain in inaccessible cracks and crevasses, or imbedded in surfaces. The amounts of material involved will usually be small in a well-designed facility. This is the case with the CIF. Also, nearly all internal surfaces of the facility are amenable to either visual or instrumental observation and verification.

By probing accessible areas, it should be possible to get a reasonable estimate of the surface contamination levels existing in the facility. A radiochemical analysis of a sample of typical surface contamination multiplied by the surface areas in Table 1 should allow a good estimation of residual activity remaining in the CIF after cleanouts. If a sample of the residual surface activity cannot be obtained, the composition should be assumed to be the same as that of the last nearby sample analyzed.

Inventories from such residuals are expected to be insignificant. For instance, there are about $\mathbf{4 5 0}$ square meters of surface area in Segment 2. Assuming a rather high contamination level of one microcurie per 100 square centimeters, Segment 2 would contain only about 45 millicuries of activity after a cleanout. Table 4 shows that the largest ICFs are for Sr-90 and Pu-239, which together make up more than half of the expected $\mathrm{HC}_{3}$ fraction sum. Assuming the activity distribution in Table 4 applies to this residual holdup material, these two nuclides would contribute less than $1 \%$ of the $\mathrm{HC} 3$ limit. 


\section{Conclusions}

A strategy of quantifying the radioactive material likely in an incineration facility is crucial to planning operations and answering worker safety, waste disposal, and regulatory questions. Using performance data expected for the CIF, inprocess distributions for the two types of facility ash were determined from the weights of burned feeds. The distributions were verified during cold operation before introducing radioactive feeds.

Estimating the distribution of radionuclides in ash from burning active wastes is not difficult. These radionuclides consist primarily of fission and activation products. Almost all are also heavy metals with atomic masses of higher than 55. When these are burned at the high temperatures in an incinerator, all are converted to their elemental or oxide forms, which are mostly refractory and insoluble. With the exception of radionuclides like tritium, C-14 and isotopes of the halogens and noble gases which are volatile, all behave like heavy metals and will be mostly found in the ash. Quench and scrub waters are kept caustic assuring that nearly all activity but tritium and the noble gases are captured. Although the fate of a few minor activities is uncertain, that of the majors is predictable and measurable.

Using site process knowledge about the concentrations of radionuclides in various input streams, their concentrations in process ash, water, and waste can be estimated. These estimates can be verified by sampling and appropriate analyses. Even without prior verification, the nature and number of assumptions used are unlikely to invalidate the technical basis for many of the issues needing to be resolved in design and startup planning.

Based on feed and CIF operational characteristics several conclusions can be made. Accounting for site-specific differences, the conclusions should be applicable to other incinerators as well. It appears that potential radiological regulatory and safety issues surrounding incineration are few and less formidable than similar chemical ones. Most feeds can be radiologically characterized quite well, so keeping radionuclide concentrations in incinerator ash or other waste at desired levels can be easily managed by adjusting volume inputs or the ratio of active to non-active feeds. And finally, although incineration does concentrate radionuclides, it also makes them more homogeneous and easier to measure by either sampling or instrumentally. For most feeds considered, and those at SRS are probably among the most varied and difficult in the industry, neither working inventories nor anticipated material holdups are expected to threaten the operational safety or regulatory compliance for the facility. 


\section{References}

1. U.S. Department of Energy, "Hazard Categorization and Accident Analysis Techniques for Compliance with DOE Order 5480.23, Nuclear Safety Analysis Reports", DOE-STD-1027-92, Washington DC (1992).

2. Westinghouse Savannah River Company, "Auditable Safety Analysis, Consolidated Incineration Facility", WSRC-TR-96-0212, Rev. 1, Savannah River Site, Aiken, SC 29808 (1996).

3. Westinghouse Savannah River Company, "Hazards Assessment Document, Consolidated Incineration Facility, "WSRC-TR-93-070 Rev. 2, Savannah River Site, Aiken, SC 29808 (1996).

4. R.C. Hochel, "Determining Radionuclides in Low-Level Waste-Analytical Reality vs. Perception (U)," USDOE Report WSRC-TR-95-0181. Rev. 1, Savannah River Site, Aiken, SC 29808 (1995).

5. U.S. Department of Energy, "Management of Low-Level Waste," Order 5820.2A, Chapter III (1988).

6. Westinghouse Savannah River Company, "Savannah River Site Waste Acceptance Criteria Manual," USDOE Manual WSRC-1S, WAC 3.13, Rev.1, Savannah River Site, Aiken, SC 29808 (1997).

7. Westinghouse Savannah River Company, "Savannah River Site Waste Acceptance Criteria Manual," USDOE Manual WSRC-1S, WAC 3.10, Rev.2, Savannah River Site, Aiken, SC 29808 (1995).

8. The General Electric Company, "Cart of the Nuclides," Thirteenth Edition (1983).

9. M.J. Bell, "ORIGEN-Oak Ridge Isotope Generation and Depletion Code," USAEC Report ORNL-4638 (May 1973).

10. R.C. Hochel, "A New Method of Characterizing Large Volumes of Low-Level Waste by Direct Liquid Scintillation Spectroscopy of Filter Paper Test Smears (U)," USDOE Report WSRC-MS-93-306, Savannah River Site, Aiken, SC 29808 (1993). 
APPENDIX

Table A-1

WTS Radionuclide List (Ref. 3)

\begin{tabular}{|c|c|c|c|c|c|}
\hline Radionuclide ${ }^{*}$ & $\begin{array}{c}\text { Hazard } \\
\text { Category } 3 \\
\text { Threshold* } \\
\text { (Ci) }\end{array}$ & $\begin{array}{c}\text { ICF } \\
(1 / C i)\end{array}$ & Radionuclide $^{*}$ & $\begin{array}{c}\text { Hazard } \\
\text { Category } 3 \\
\text { Threshold } \\
\text { (Ci) }\end{array}$ & $\begin{array}{c}\text { ICF } \\
(1 / C i)\end{array}$ \\
\hline $\mathrm{H}-3$ & $1.00 \mathrm{E}+03$ & $1.00 \mathrm{E}-03$ & $\mathrm{Nb}-94$ & $2.00 \mathrm{E}+02$ & $5.00 \mathrm{E}-03$ \\
\hline $\mathrm{Be}-7$ & $1.40 \mathrm{E}+04$ & 7.14E-05 & $\mathrm{Nb}-95$ & $9.60 \mathrm{E}+02$ & $1.04 \mathrm{E}-03$ \\
\hline C-14 & $4.20 \mathrm{E}+02$ & $2.38 E-03$ & $\mathrm{Nb}-95 \mathrm{~m}$ & $5.60 \mathrm{E}+03$ & $1.79 \mathrm{E}-04$ \\
\hline $\mathrm{Na}-22$ & $2.40 \mathrm{E}+02$ & 4.17E-03 & Mo-99 & $3.40 \mathrm{E}+03$ & 2.94E-04 \\
\hline $\mathrm{Na}-24$ & $3.00 \mathrm{E}+02$ & 3.33E03 & TC-99 & $1.70 \mathrm{E}+03$ & 5.88E-04 \\
\hline P-32 & $1.20 \mathrm{E}+01$ & 8.33E-02 & $\mathrm{Ru}-103$ & $1.50 \mathrm{E}+03$ & 6.67E-04 \\
\hline $\mathrm{P}-33$ & $9.40 \mathrm{E}+01$ & 1.06E-02 & $\mathrm{Ru}-105$ & $4.00 \mathrm{E}+03$ & $2.50 \mathrm{E}-04$ \\
\hline P-32, acid & $1.20 E+01$ & 8.33E-02 & Ru-106 & $1.00 E+02$ & 1.00E-02 \\
\hline$P-33$, acid & $9.40 \mathrm{E}+01$ & $1.06 E-02$ & Rh-102m & $6.20 E+02$ & 1.61E-03 \\
\hline S-35 & $7.80 E+01$ & $1.28 \mathrm{E}-02$ & $\mathrm{Rh}-106$ & $1.96 E+03$ & 5.10E-04 \\
\hline $\mathrm{Cl}-36$ & $3.40 E+02$ & $2.94 E-03$ & $\mathrm{Pd}-107$ & $4.20 \mathrm{E}+03$ & $2.38 E-04$ \\
\hline $\mathrm{K}-40$ & $1.70 \mathrm{E}+02$ & 5.88E-03 & $\mathrm{Ag}-110 \mathrm{~m}$ & $2.60 \mathrm{E}+02$ & $3.85 E-03$ \\
\hline $\mathrm{Ca}-45$ & $1.10 \mathrm{E}+03$ & $9.09 E-04$ & $\mathrm{Cd}-109$ & $1.80 \mathrm{E}+02$ & 5.56E-03 \\
\hline $\mathrm{Ca}-47$ & $7.00 \mathrm{E}+02$ & 1.43E-03 & $\mathrm{Cd}-113$ & $1.10 \mathrm{E}+01$ & $9.09-02$ \\
\hline Sc-46 & $3.60 \mathrm{E}+02$ & 2.78E-03 & $\mathrm{Cd}-115 \mathrm{~m}$ & $2.20 \mathrm{E}+02$ & $4.55 E-03$ \\
\hline Ti-44 & $6.20 \mathrm{E}+01$ & 1.61E-02 & $\ln -114 \mathrm{~m}$ & $2.20 \mathrm{E}+02$ & $4.55 E-03$ \\
\hline$V-48$ & $6.40 E+02$ & $1.56 \mathrm{E}-03$ & $S n-113$ & $1.30 \mathrm{E}+03$ & $7.69 E-04$ \\
\hline $\mathrm{Cr}-51$ & $2.20 E+04$ & 4.55E-05 & $\mathrm{Sn}-121 \mathrm{~m}$ & $1.90 \mathrm{E}+03$ & 5.26E-04 \\
\hline $\mathrm{Mn}-52$ & $3.40 E+02$ & 2.94E-03 & Sn-123 & $3.20 E+02$ & $3.13 E-03$ \\
\hline $\mathrm{Mn}-54$ & $8.80 E+02$ & $1.14 \mathrm{E}-03$ & Sn-126 & $1.70 E+02$ & $5.88 \mathrm{E}-03$ \\
\hline $\mathrm{Fe}-55$ & $5.40 E+03$ & $1.85 E-04$ & $\mathrm{sb}-120 \mathrm{~m}$ & $3.20 E+02$ & $3.13 E-03$ \\
\hline Fe-59 & $6.00 \mathrm{E}+02$ & 1.67E-03 & Sb-124 & $3.60 E+02$ & 2.78E-03 \\
\hline Co-57 & $6.00 \mathrm{E}+03$ & 1.67E-04 & $\mathrm{Sb}-125$ & $1.20 \mathrm{E}+03$ & 8.33E-04 \\
\hline $\mathrm{Co}-58$ & $9.00 E+02$ & 1.11E-03 & $\mathrm{Sb}-126$ & $2.80 E+02$ & $3.57 E-03$ \\
\hline Co-60 & $2.80 \mathrm{E}+02$ & 3.57E-03 & $\mathrm{Sb}-126 \mathrm{~m}$ & $2.40 E+04$ & 4.17E-05 \\
\hline Ni-59 & $1.18 E+04$ & 8.47E-05 & $\mathrm{Te}-125 \mathrm{~m}$ & $7.20 \mathrm{E}+02$ & 1.39E-03 \\
\hline $\mathrm{Ni}-63$ & $5.40 E+03$ & 1.85E-04 & $\mathrm{Te}-127$ & $1.40 E+05$ & $7.14 E-06$ \\
\hline $\mathrm{Zn}-65$ & $2.40 E+02$ & 4.17E-03 & $\mathrm{Te}-127 \mathrm{~m}$ & $4.00 \mathrm{E}+02$ & 2.50 E-03 \\
\hline Ge-68 & $1.00 \mathrm{E}+03$ & $1.00 \mathrm{E}-03$ & Te-129 & $2.20 \mathrm{E}+05$ & 4.55E-06 \\
\hline Se-75 & $3.20 \mathrm{E}+02$ & $3.13 E-03$ & $\mathrm{Te}-129 \mathrm{~m}$ & $4.00 \mathrm{E}+02$ & $2.50 \mathrm{E}-03$ \\
\hline Se-79 & $3.60 \mathrm{E}+02$ & $2.78 E-03$ & I-125 & 5.60E-01 & $1.79 E+00$ \\
\hline $\mathrm{Kr}-85$ & $2.00 \mathrm{E}+04$ & 5.00 E-05 & l-129 & $6.00 \mathrm{E}-02$ & 1.67E+01 \\
\hline $\mathrm{Rb}-87$ & $6.00 E+02$ & 1.67E-03 & $\mid-131$ & $9.20 \mathrm{E}-01$ & $1.09 E+00$ \\
\hline Sr-85 & $1.40 \mathrm{E}+03$ & $7.14 E-04$ & Xe-133 & $2.00 \mathrm{E}+04$ & $5.00 E-05$ \\
\hline Sr-89 & $3.40 \mathrm{E}+02$ & 2.94E-03 & Cs-134 & $4.20 E+01$ & $2.38 E-02$ \\
\hline Sr-90 & $1.60 \mathrm{E}+01$ & $6.25 E-02$ & Cs-135 & $4.20 E+02$ & $2.38 E-03$ \\
\hline Sr-91 & $1.50 E+03$ & 6.67E-04 & Cs-137 & $6.00 E+01$ & 1.67E-02 \\
\hline Sr-92 & $3.40 \mathrm{E}+03$ & 2.94E-04 & $\mathrm{Ba}-133$ & 1. $10 \mathrm{E}+03$ & $9.09 E-04$ \\
\hline$Y-88$ & $2.80 \mathrm{E}+02$ & $3.57 E-03$ & $\mathrm{Ba}-140$ & $6.00 E+02$ & $1.67 E-03$ \\
\hline $\mathrm{Y}-90$ & $1.41 E+03$ & $7.09 E-04$ & La-140 & $4.00 E+02$ & $2.50 E-03$ \\
\hline$Y-91$ & $3.60 \mathrm{E}+02$ & $2.78 \mathrm{E}-03$ & $\mathrm{Ce}-141$ & $1.00 \mathrm{E}+03$ & 1.00E-03 \\
\hline $\mathrm{Zr}-93$ & $6.20 E+01$ & 1.61E-02 & $\mathrm{Ce}-143$ & $3.80 E+03$ & 2.63E-04 \\
\hline$Z r-95$ & $7.00 E+02$ & $1.43 E-03$ & $\mathrm{Ce}-144$ & $1.00 \mathrm{E}+02$ & $1.00 \mathrm{E}-02$ \\
\hline
\end{tabular}


Table A-1 (cont.)

WTS Radionuclide List (Ref. 3)

\begin{tabular}{|c|c|c|c|c|c|}
\hline Radionuclide* & $\begin{array}{c}\text { Hazard } \\
\text { Category } 3 \\
\text { Threshold }^{* *} \\
\text { (Ci) }\end{array}$ & $\begin{array}{c}\text { ICF } \\
(1 / C i)\end{array}$ & Radionuclide* & $\begin{array}{c}\text { Hazard } \\
\text { Category } 3 \\
\text { Threshold } \\
\text { (Ci) }\end{array}$ & $\begin{array}{c}\text { ICF } \\
(1 / C i)\end{array}$ \\
\hline Pr-143 & $1.04 E+03$ & $9.62 \mathrm{E}-04$ & $A C-225$ & $3.20 \mathrm{E}+01$ & $3.13 \mathrm{E}-02$ \\
\hline Pr-144 & $1.04 E+06$ & $9.62 E-07$ & AC-227 & $4.20 \mathrm{E}-02$ & $2.38 E+01$ \\
\hline $\mathrm{Nd}-147$ & $1.20 E+03$ & 8.33E-04 & Ac-228 & $9.40 \mathrm{E}+02$ & 1.06E-03 \\
\hline Pm-144 & $4.80 E+02$ & 2.08E-03 & Th-228 & $1.00 \mathrm{E}+00$ & $1.00 E+00$ \\
\hline $\mathrm{Pm}-145$ & $2.00 E+03$ & 5.00 E-04 & Th-230 & $6.20 \mathrm{E}-01$ & $1.61 E+00$ \\
\hline$P m-147$ & $1.00 E+03$ & $1.00 \mathrm{E}-03$ & Th232 & $1.00 \mathrm{E}-01$ & $1.00 E+00$ \\
\hline $\mathrm{Pm}-148$ & $8.20 E+02$ & $1.22 \mathrm{E}-03$ & Th-234 & $2.80 E+03$ & 3.57E-04 \\
\hline$P m-148 m$ & $3.60 E+02$ & $2.78 \mathrm{E}-03$ & $\mathrm{U}-232$ & $8.20 \mathrm{E}-01$ & $1.22 \mathrm{E}+00$ \\
\hline Sm-147 & 4.10E-01 & $2.44 E+00$ & U-233 & $4.20 E+00$ & $2.38 E-01$ \\
\hline Sm-151 & $1.00 E+03$ & $1.00 \mathrm{E}-03$ & $\mathrm{U}-234$ & $4.20 E+00$ & 2.38E-01 \\
\hline Eu-152 & $2.00 E+02$ & $5.00 \mathrm{E}-03$ & $\mathrm{U}-235$ & $1.55 \mathrm{E}-03$ & $6.45 E+02$ \\
\hline Eu-154 & $2.00 E+02$ & $5.00 \mathrm{E}-03$ & $\mathrm{U}-236$ & $4.20 \mathrm{E}+00$ & 2.38E-01 \\
\hline Eu-155 & $9.40 \mathrm{E}+02$ & $1.06 \mathrm{E}-03$ & U-238 & $4.20 \mathrm{E}+00$ & 2.38E-01 \\
\hline Eu-156 & $4.60 \mathrm{E}+02$ & 2.17E-03 & $\mathrm{Np}-236$ & $2.40 E+00$ & 4.17E-01 \\
\hline Gd-153 & $1.00 \mathrm{E}+03$ & $1.00 \mathrm{E}-03$ & $\mathrm{~Np}-237$ & $4.20 \mathrm{E}-01$ & $2.38 E+00$ \\
\hline Tb-160 & $5.60 E+02$ & 1.79E-03 & Np-238 & $1.30 E+03$ & $7.69 \mathrm{E}-04$ \\
\hline Ho-166m & $7.20 E+01$ & 1.39E-02 & $\mathrm{Np}-239$ & $7.80 E+03$ & $1.28 \mathrm{E}-04$ \\
\hline $\mathrm{Tm}-170$ & $5.20 \mathrm{E}+02$ & 1.92E-03 & $\mathrm{Pu}-236$ & $2.00 E+00$ & $5.00 \mathrm{E}-01$ \\
\hline $\mathrm{Hf}-181$ & $7.60 \mathrm{E}+02$ & 1.32E-03 & Pu-238 & $6.20 \mathrm{E}-01$ & $1.61 E+00$ \\
\hline Ta-182 & $6.20 E+02$ & 1.61E-03 & Pu-239 & $5.20 \mathrm{E}-01$ & $1.92 E+00$ \\
\hline$W-188$ & $2.80 \mathrm{E}+02$ & 3.57E-03 & $P u-240$ & 5.20E-01 & $1.92 \mathrm{E}+00$ \\
\hline Re-184 & $9.00 \mathrm{E}+02$ & 1.11E:03 & $\mathrm{Pu}-241$ & $3.20 E+01$ & $3.13 \mathrm{E}-02$ \\
\hline $\mid r-192$ & $9.40 \mathrm{E}+02$ & $1.06 \mathrm{E}-03$ & Pu-242 & $6.20 \mathrm{E}-01$ & $1.61 \mathrm{E}+00$ \\
\hline Pt-195m & $5.00 \mathrm{E}+03$ & 2.00E-04 & Am-241 & $5.20 \mathrm{E}-01$ & $1.92 \mathrm{E}+00$ \\
\hline Au-195 & $3.20 \mathrm{E}+03$ & $3.13 E-04$ & $A m-242 m$ & $5.20 \mathrm{E}-01$ & $1.92 E+00$ \\
\hline Au-198 & $2.00 \mathrm{E}+03$ & $5.00 \mathrm{E}-04$ & Am-243 & 5.20E-01 & $1.92 E+00$ \\
\hline $\mathrm{Hg}-203$ & $3.60 \mathrm{E}+02$ & $2.78 E-03$ & $\mathrm{Cm}-242$ & $3.20 E+01$ & $3.13 \mathrm{E}-02$ \\
\hline Tl-204 & $1.20 E+03$ & $8.33 \mathrm{E}-04$ & $\mathrm{Cm}-243$ & $8.20 \mathrm{E}-01$ & $1.22 \mathrm{E}+00$ \\
\hline $\mathrm{Pb}-210$ & 3.60 E-01 & $2.78 E+00$ & $\mathrm{Cm}-244$ & $1.04 \mathrm{E}+00$ & 9.62E-01 \\
\hline $\mathrm{Bi}-207$ & $5.00 \mathrm{E}+02$ & $2.00 \mathrm{E}-03$ & $\mathrm{Cm}-245$ & $5.20 \mathrm{E}-01$ & $1.92 E+00$ \\
\hline $\mathrm{Bi}-205$ & $8.80 E+02$ & 1.14E-03 & $\mathrm{Cm}-246$ & $5.20 \mathrm{E}-01$ & $1.92 E+00$ \\
\hline $\mathrm{Bi}-210$ & $3.20 \mathrm{E}+02$ & $3.13 E-03$ & $\mathrm{Cm}-247$ & $6.20 \mathrm{E}-01$ & $1.61 E+00$ \\
\hline Po-210 & $1.90 E+00$ & $5.26 \mathrm{E}-01$ & $\mathrm{Cm}-248$ & $1.00 \mathrm{E}-01$ & $1.00 \mathrm{E}+01$ \\
\hline Rn-222 & $1.00 E+01$ & $1.00 \mathrm{E}-01$ & Cf-249 & $5.20 \mathrm{E}-01$ & $1.92 E+00$ \\
\hline Ra-223 & $6.20 \mathrm{E}+01$ & 1.61E-02 & Cf-250 & $1.04 E+00$ & $9.62 \mathrm{E}-01$ \\
\hline Ra-224 & $2.00 E+02$ & $5.00 \mathrm{E}-03$ & Cf-251 & $5.20 \mathrm{E}-01$ & $1.92 E+00$ \\
\hline $\mathrm{Ra}-225$ & $7.20 E+01$ & 1.39E-02 & Cf-252 & $3.20 E+00$ & $3.13 E-01$ \\
\hline Ra-226 & $1.20 \mathrm{E}+01$ & $8.33 E-02$ & $\begin{array}{c}\text { Other } \\
\text { Beta/Gamma }\end{array}$ & $1.60 \mathrm{E}+01$ & $6.25 E-02$ \\
\hline Ra-228 & $1.20 \mathrm{E}+01$ & $8.33 \mathrm{E}-02$ & Other Alpha & $5.20 \mathrm{E}-01$ & $1.92 \mathrm{E}+00$ \\
\hline
\end{tabular}

* This table includes all radionuclides previously identified in CIF waste stream evaluations except $\mathrm{Ba}-137 \mathrm{~m}, \mathrm{Pr}-144 \mathrm{~m}, \mathrm{Ag}-110$, and $\mathrm{Pa}-234 \mathrm{~m}$. These radionuclides are short lived isotopes and are accounted for when establishing the threshold limits of their respective parent isotopes.

** This list of Hazard Category 3 thresholds is an expanded version of the list found in DOE-STD-1027-92 (Ref. 1) and was obtained from the CIF Hazard Assessment Document (Ref. 3). 